\title{
Biochemical changes during composting of coir pith waste as influenced by different agro industrial wastes
}

\author{
T. Muthurayar ${ }^{1}$, M. S. Dhanarajan ${ }^{2}$ \\ ${ }^{1}$ Research Scholar, Sathyabama University, Chennai; rayar_jega@yahoo.com \\ ${ }^{2}$ Principal, Jaya College, Thiruninravoor
}

Received 2013

\begin{abstract}
Coir pith, a byproduct of coconut husk is difficult to decompose due to its high lignin and cellulose content. In this study, coir pith was composted with different agro industrial by products such as cow dung, vegetable market waste, poultry waste and microbial consortium. The different treatment combinations used in the present study were Control, T1 (Coir pith + Cow dung + Vegetable market waste + Poultry waste + mixed microbial culture (Trichoderma viridae + Pleurotus sajar caju), T2 (Coir pith + Vegetable market waste + Poultry waste + Tank slit + Mixed microbial culture) and T3 (Coir pith + Cow dung + poultry waste + tank slit + mixed microbial culture). At the end of $12^{\text {th }}$ week, in the treatment T1, C: $\mathrm{N}$ ratio of 21.8:1 was observed in the composted coir pith sample. Highest $P$ content of $0.47 \%$ and $K$ content of $1.2 \%$ and the least Cellulose and Lignin contents of $22.8 \%$ and $10.03 \%$ were recorded in the T1 treatment after a composting period of 12 weeks. Highest pH of 7.4 was observed in the treatment T3, this was followed by T1 (7.2) treatment.
\end{abstract}

Keywords: Coir Pith Compost; Agro Industrial Wastes; C:N Ratio; Trichoderma Viridae and Pleurotus Sajar Caju

\section{INTRODUCTION}

Composting is the biological decomposition and stabilization of organic substrates under conditions that allow development of thermophilic temperature, to produce a final stable product, free of pathogens and weed seeds and can be beneficially applied to crops. Composting has a wide range of applications in agriculture, economy, and environment [6]. In composting the wastes are converted into value added products that help to increase the reve- nue of the farmers and industrialists since waste and the by-product of one industry can be raw material for another industry [2]. Coir pith has high moisture retention property (500\% - 600\%) and K content. These properties could be successfully exploited for agricultural use.

Taking this into account, the present investigation was undertaken with an attempt to convert the carbon rich materials into compost using various industrial wastes and microbes by utilizing different treatment methods.

\section{MATERIALS AND METHODS}

\subsection{Collection of Samples}

The coir pith materials were collected from Uthamapalayam, Theni district, Tamilnadu, India.

\subsection{Experimental Details}

The experiment was conducted in time duration of 12 weeks. For this experiment coir pith was mixed with various components such as cow dung; vegetables market waste, poultry waste, tank slit and microbial mixed cultures. Coir pith treated with above additives to enhance the composting efficiency (Table 1).

Table 1. The Experimental details of the different treatments used for biocomposting of coir pith waste.

\begin{tabular}{ll}
\hline Treatments & Details of industrial waste components \\
\hline C & Coir pith \\
T1 & $\begin{array}{l}\text { Coir pith + Cow dung + Vegetable market waste + } \\
\text { Poultry waste }+ \text { Mixed microbial culture (Tricho- } \\
\text { derma viridae }+ \text { Pleurotus sajarcaju) }\end{array}$ \\
T2 & $\begin{array}{l}\text { Coir pith }+ \text { Vegetable market waste }+ \text { Poultry } \\
\text { waste }+ \text { Tank slit }+ \text { Mixed microbial culture }\end{array}$ \\
T3 & $\begin{array}{l}\text { Coir pith + Cow dung + poultry waste + tank slit }+ \\
\text { Mixed microbial culture }\end{array}$ \\
\hline
\end{tabular}




\subsection{Compost Bed Preparation}

Organic additives were weighed on fresh weight basis and added individually. Coir pith was spread and compacted well to get a layer of combination using different additives such as cow dung, vegetable market waste, mixed microbial culture, tank slit and poultry waste. 10 mg of Microbial cultures (Inoculation load $1 \times 10^{7} \mathrm{Cfu}$ ) was added and a moisture content of $50 \%$ - 60\% was maintained. Height of each layer was maintained at a height of $10 \mathrm{~cm}$. Over this another layer was made with coir pith. This procedure was repeated and finally the top of each cistern was covered with soil slurry. Turning was given once in every three weeks and required reading was made periodically. At the end of the $12^{\text {th }}$ week, the samples were analyzed for their biochemical properties such as organic carbon, nitrogen, phosphorous and potassium according to the methods of Sadashivam and Manickam [5] and Jackson [3]. Cellulose and Lignin content of the samples were determined periodically according to the methods of Ververis et al. [7]. The initial Biochemical composition of raw coir pith is presented in Table 2. The final biochemical constituents were determined at the end of $12^{\text {th }}$ week according to the protocols as described earlier.

\section{RESULTS}

Biochemical composition of raw coir pith was evaluated and presented in Table $\mathbf{1}$. Raw coir pith recorded phosphorous, potassium, cellulose and lignin contents of $0.02,0.30,35.7$ and 54.3\%, respectively. The $\mathrm{pH}$ was found to be acidic (5.4) and C: $\mathrm{N}$ ratio was found to be high (162:1).

Changes in the different biochemical constituents such as C: N ratio, Phosphorous, Potassium, Cellulose, and lignin contents and $\mathrm{pH}$ was recorded at different intervals. There was a steep decrease in the $\mathrm{C}$ : $\mathrm{N}$ ratio at the end of third week and this trend continued up to a period of $12^{\text {th }}$ week. At the end of $12^{\text {th }}$ week in treatment T1, a C: N ratio of 21.8:1 was observed in the composted coir pith sample. Irrespective of the observed samples there was a slight increase in the $\mathrm{pH}$ content of samples. Highest $\mathrm{pH}$ of 7.4 was observed in the treatment T3; this was followed by $\mathrm{T} 1$ and $\mathrm{T} 2$ treatments that recorded a $\mathrm{pH}$ of 7.2 and 6.7, respectively. There was an increase in the $\mathrm{K}$ content of coir pith as influenced by different treatment methods. This increase was found to be significantly higher in all treatments, when compared to control. Highest $\mathrm{K}$ content of $1.2 \%$ was recorded in the $\mathrm{T} 1$ Treatment. No significant differences in $\mathrm{P}$ content were observed in all treatments, when compared to control treatment up to a time period of 2 weeks. After a period of 3 weeks a steep increase in P content was observed. This increase was found to significantly higher, compared to control. Maximum P content of $0.47 \%$ was ob- served in T1 Treatment, followed by $0.45 \%$, and $0.39 \%$ in T2, and T3, respectively (Table 2).

Cellulose content of all treatments was found to be significantly decreased at the end of 12 weeks of composting period. However, no significant differences among different treatments were observed during the entire period. At the end of the $12^{\text {th }}$ week of composting period the cellulose content recorded in T1, T2, and T3 treatments, were $22.8 \%$, $25.8 \%$ and $27.3 \%$, respectively. Lignin content among treatments was found to be significantly decreased after $9^{\text {th }}$ week of treatment. At the end of the composted period of $12^{\text {th }}$ week the lignin content recorded at different treatments were $\mathrm{T} 1, \mathrm{~T} 2$, and $\mathrm{T} 3$ were $10.3 \%, 15.3 \%$ and $23.3 \%$.

At the end of composting period of 12 weeks the different biochemical constituents of the composted coir pith was analyzed and presented in table 2. The least C: $\mathrm{N}$ ratio of 21.8: 1 , cellulose content of $22.8 \%$ and lignin content of 10.3 was observed in the T1 treatment (Table 3).

Table 2. Biochemical Composition of raw coir pith.

\begin{tabular}{ll}
\hline Properties & Values \\
\hline Organic carbon(\%) & 50.4 \\
Nitrogen(\%) & 0.31 \\
Phosphorus(\%) & 0.02 \\
Potassium(\%) & 0.30 \\
Cellulose(\%) & 35.7 \\
Lignin (\%) & 54.3 \\
pH & 5.4 \\
EC & 1.5 \\
C:N & $162: 1$ \\
\hline
\end{tabular}

Table 3. Biochemical Composition of composted coir pith as influenced by different treatments.

\begin{tabular}{lcccc}
\hline Properties & \multicolumn{4}{c}{ Values } \\
\hline Treatments & Control & T1 & T2 & T3 \\
Organic carbon (\%) & 42.07 & 28.01 & 30.0 & 28.7 \\
Nitrogen(\%) & 1.02 & 1.28 & 1.25 & 1.24 \\
Phosphorus(\%) & 0.02 & 0.47 & 0.45 & 0.39 \\
Potassium(\%) & 0.42 & 1.2 & 0.89 & 0.77 \\
Cellulose (\%) & 31.3 & 22.8 & 25.8 & 27.3 \\
Lignin (\%) & 48.7 & 10.3 & 15.1 & 23.3 \\
pH & 6.0 & 7.2 & 7.4 & 6.7 \\
C:N & 41.2 & 21.8 & 31.3 & 23.1 \\
\hline
\end{tabular}




\section{DISCUSSION}

Significant changes in OC, lignin and cellulose content were observed among the different treatments. This results are in line with the findings of Barder and Crawdford [1], who reported that the $\mathrm{C}$ : $\mathrm{N}$ ratio narrowed when coir pith was composted with different additives such as these workers attributed this higher decomposition ratio the presence of adequate nutrients.

After 12 weeks of composting period there was a considerable increase in the $\mathrm{N}, \mathrm{P}$, and $\mathrm{K}$ contents among the different treatments Kadalli et al. [4] observed highest $\mathrm{N}$ and $\mathrm{P}$ contents in coir pith, composted with Pleurotus, cow dung, garden weeds, sun-hemp, rock phosphate and micronutrients. These authors also reported that in this study the $\mathrm{N}$ content of the composts ranged from 1.02\% to $1.38 \%$ and the OC content ranged from $30.24 \%$ to $43.76 \%$ and $\mathrm{C}: \mathrm{N}$ ratio has been drastically reduced to 21.91 due to increase in $\mathrm{N}$ content and loss of carbon as $\mathrm{CO}_{2}$.

\section{ACKNOWLEDGEMENTS}

The authors thank the authorities of Sathyabama University for their support in executing this Research Project.

\section{REFERENCES}

[1] Border, M.T. and Crawford, D.L (1981) Effects of carbon and nitrogen supplementation on lignin and cellulose decomposition by a Streptomyces. Canadian Journal of Microbiology, 27, 859-63. doi: $10.1139 / \mathrm{m} 81-136$

[2] Iranpour, R., Stenstrom, M., Tchobanoglous, G., Miller, D., Wright, J. and Vossoughi, M. (1999) Environmental engineering; Energy value of replacing waste Disposal with resource recovery. Science, 285, 706-711. doi: 10.1126/science.285.5428.706

[3] Jackson, M.L. (1973) Soil Chemical Analysis, Prentice Hall of India Pvt Ltd .,New Delhi, 1-485.

[4] Kadalli, G.G., Suseela Devi, L., Siddaramappa, R. and Patil, C.R. (2000). Quality and effiency of value added Coir-dust based compost. J. Indian Society of Soil Science, 48, 141-144.

[5] Sadasivam, S. and Manickam, A. Biochemical Methods, New Age International (P) Ltd, Publishers, $2^{\text {nd }}$. Edn. May 1996.

[6] Saravanan. S, Meenabal. T and Uma R. N. (2003) Study on Biodegradation of fruit waste aerobic composting in Martin J. Bunch Health,(15-17), December 2003, Department of Geography, University of Madras and Faculty of Environmental Studies, New York university, 441-450.

[7] Ververis, C., Geoghior K., Danielidies, D., Hatzinikolau, D.G., Santas, P., Santas, R. and Corteti, V. (2006) Cellulose, hemicelluloses, lignin and ash content of same organic materials and their suitability for use as paper supplements. Bioresource Technoogyl, 98, 296-301. doi: 10.1016/j. biortech.2006.01.007 